\section{Sant om legemidler?}

Leger tar viktige valg på vegne av sine pasienter når de anbefaler bruk av bestemte medisiner. Allmennleger arbeider i små fagmiljøer, skriver ut mange resepter og velger legemidler på nokså fritt grunnlag. De er derfor en viktig målgruppe for legemiddelreklamen. Direkte legemiddelreklame overfor helsepersonell utgjør likevel bare ett aspekt ved markedsføringen. Viktigst er trolig den industrisponsede forskningen som ender opp i publiserte artikler. Det er til sjuende og sist disse som ligger til grunn for kunnskapsoppsummeringer og kliniske retningslinjer, det som igjen styrer forskrivernes legemiddelvalg. Både legemiddelreklame og den industrisponsede forskningen bør gjennomgås kritisk fra tid til annen.

I dette nummer av Tidsskriftet presenterer Gladsø og medarbeidere en studie om skriftlig legemiddelreklame mottatt i posten ved to allmennlegekontorer i Trondheim sommeren 2012 (1). De følger opp funn fra 2004, der bare halvparten av reklamen var korrekt og klinisk relevant og der Legemiddelindustrien (LMI) repliserte at de ville forbedre den faglige standarden på legemiddelinformasjonen. Gjennomgangen av reklamen fra 2012 tyder imidlertid ikke på at markedsføringen er særlig endret. Fortsatt er bare omkring halvparten av påstandene i reklamen korrekte, relevante og i samsvar med legemiddelforskriften. Forfatterne gir tankevekkende eksempler på at reklamen viser til studier med tvilsom kvalitet og at informasjonen også kan være temmelig selektiv.

De aller fleste legemiddelstudier er industrifinansiert. Der det finnes uavhengige studier innenfor samme område, er det påfallende at den industrisponsede forskningen ofte viser langt gunstigere effekt av fors $\varnothing \mathrm{ksmedisinene} \mathrm{enn} \mathrm{den} \mathrm{uavhengige} \mathrm{forskningen.}$ Dette er vist over tid og innenfor flere ulike fagområder (2). Derfor burde de som har ansvar for å oppsummere legemiddelforskning, for eksempel Kunnskapssenteret, innarbeide industrisponsing mer eksplisitt som sorteringsvariabel i sine analyser.

Det kan være mange årsaker til «publication bias», systematisk publiseringsskjevhet. Vanligst er trolig at firmaet ikke har sett seg tjent med å publisere en såkalt negativ studie. Det er nemlig fortsatt slik at et firma fullt lovlig kan bestemme fritt hva de ønsker å publisere og hva de heller vil legge i skuffen - selv om det i Helsinkideklarasjonen er nedfelt en forskningsetisk plikt til å offentliggjøre alle resultater. Når industrisponsede studier blir publisert, er det ofte firmaet som bekoster dataanalyser og utarbeiding av artikkelutkast utført av profesjonelle artikkelskrivere (ghost writers) (3).

Med full kontroll på hele forskningsprosessen burde det ikke overraske at mange firmaer prioriterer å bekoste formidling av studier der resultatene er omsetningsfremmende. Historien om influensamedisinene oseltamivir og zanamivir illustrerer hvor stor betydning det har at data fra kliniske studier holdes tilbake, men også hvordan langvarig strev for offentliggjøring faktisk kan føre frem. I 2009 raste svineinfluensaen over hele verden. Både helsemyndigheter og privatpersoner hamstret influensamedisiner i tillit til at midlene effektivt kunne forebygge alvorlige komplikasjoner og død. Milliarder av kroner ble brukt. Under arbeidet med en Cochrane-rapport i 2009 ble imidlertid forfatterne gjort oppmerksom på at resultater fra flere viktige kliniske studier med disse medisinene ikke var publisert. Først etter over tre års hardt press ga produsentene av influensamedisin etter. I 2013 var komplette rapporter fra alle studier gjort tilgjengelig (4). Analyser av disse dataene nå i 2014 viser at hovedeffekten ikke utgjorde mer enn en halv dag kortere senge- leie. Det var ingen påvisbar effekt på verken sykehusinnleggelser eller død (4).

Det siste tiåret har det vært noen milepæler i arbeidet for større åpenhet om klinisk forskning. Tidsskriftredaktører i International Committee of Medical Journal Editors har fra 2005 krevd forhåndsregistrering av kliniske studier, og fra 2007 har også Food and Drug Administration i USA krevd dette. Likevel er det dessverre fortsatt slik at mange nye studieresultater aldri blir rapportert, samtidig som det finnes ukjente mengder ikke-tilgjengelig dokumentasjon om de fleste medisiner pasienter bruker i dag. Legemiddelmyndighetene får tilgang til mer enn offentligheten for øvrig, men saken med influensamedisinene viste at heller ikke de har tilgang til alt (4).

I 2013 ble arbeidsgruppen og kampanjen alltrials.net lansert. Mer enn 500 nasjonale og internasjonale organisasjoner og rundt 80000 mennesker har så langt sluttet opp om kampanjen. Den har som formål å arbeide for at alle kliniske studier skal registreres og alle resultater gjøres tilgjengelig for helsemyndigheter, forskere og pasienter. I 2013 så det ut til at kampanjen ville lykkes og at European Medicines Agency (EMA) ville kreve at resultater fra all klinisk forskning skulle gjøres offentlig tilgjengelig. På forsommeren 2014 gjorde imidlertid EMA helomvending og presenterte et utvannet lovforslag. En eventuell tilgang til resultater skulle kun gis etter særskilt tillatelse og bare via innsyn på skjerm (dokumentene er typisk på flere tusen sider), uten mulighet til å laste ned, skrive ut eller på annen måte hente ut tall. Dermed ville dataene i praksis fortsatt være utilgjengelige. Mange protesterte mot det nye forslaget, og nå ser det ut til at siste ord fortsatt ikke er sagt. Lovarbeidet er i støpeskjeen på nytt, og en avgjørelse er varslet i løpet av høsten 2014 (5).

Inntil alle resultater fra alle studier er offentlig tilgjengelige kan vi ikke stole blindt på kunnskap fra oppsummert industrisponset forskning. Og reklamen? Den egner seg fortsatt best i esken for resirkulerbart papir.

\section{Anja Maria Brænd}

a.m.l.brand@medisin.uio.no Jørund Straand

Anja Maria Brænd (f. 1980) er lege og ph.d.-stipendiat ved Avdeling for allmennmedisin, Universitetet i Oslo

Forfatter har fylt ut ICMJE-skjemaet og oppgir ingen interessekonflikter.

Jørund Straand (f. 1951) er professor i allmennmedisin og avdelingsleder ved Avdeling for allmennmedisin, Universitetet i Oslo.

Forfatter har fylt ut ICMJE-skjemaet og oppgir ingen interessekonflikter.

\section{Litteratur}

1. Glads $\varnothing \mathrm{KH}$, Garberg HR, Spigset 0 et al. Skriftlig legemiddelreklame - fremdeles ikke til å stole på? Tidsskr Nor Legeforen 2014; 134: 1563-8.

2. Lundh A, Sismondo S, Lexchin J et al. Industry sponsorship and research outcome. Cochrane Database Syst Rev 2012; 12: MR000033.

3. Hill KP, Ross JS, Egilman DS et al. The ADVANTAGE seeding trial: a review of internal documents. Ann Intern Med 2008; 149: 251-8.

4. Jefferson T, Doshi P. Multisystem failure: the story of anti-influenza drugs. BMJ 2014; 348: g2263.

5. AllTrials. EMA postpones decision on clinical trial data sharing policy. www.alltrials.net/news/ema-postpones-decision-on-clinical-trial-datasharing-policy/http://www.alltrials.net/news/ema-data-sharing-policy-couldput-transparency-at-risk/ (5.8.2014). 